Exeter RIME conference 2007

Keynote presentation

\title{
Group cooperation, inclusion and disaffected pupils: some responses to informal learning in the music classroom
}

\section{Lucy Green}

\begin{abstract}
This paper examines some personal and inter-personal issues concerning group-work and informal learning in the music classroom. It analyses data from a recent research project, which adopted and adapted the informal music learning practices of popular musicians, for use in the classroom. The discussion focuses on three aspects of the project. Firstly, it considers the issue of group cooperation, or the ways in which pupils interacted to organise their learning in small groups. This includes various approaches, identified as 'group learning', 'peer-directed learning' and 'leadership'. Secondly, the paper addresses the topic of inclusion in relation to how individuals with differing needs and experiences were able to respond to the project, and the extent to which the learning practices allowed differentiation. Thirdly, weaving through the first two strands, the paper examines the inclusion of pupils who had been identified by their teachers as disaffected. This involves considering the roles of imaginative play and personal identity in the music classroom, with relation to both music's cultural delineations and its sonic properties.
\end{abstract}

\section{Note}

This is a written version of what was originally a spoken presentation. I have attempted to be as faithful to the original as possible, only inserting a minimum of 
additional information in the form of brief footnotes and references; and adding a few additional quotes from teachers. Where in the presentation I played audio-recordings of pupils working together, here I have presented rough transcripts instead, or attempted to generally describe what was on the recording. Some of the transcripts are drawn from longer sections of the recording than I had time to play during the presentation. The transcripts are intended to give the flavour of events rather than a totally accurate account. In many cases more than one person was speaking at a time, and there was a considerable amount of other sound from recorded music and instruments being played.

The research was originally funded by the Esmée Fairbairn Foundation, and subsequently had major support from the Paul Hamlyn Foundation and the UK Department for Education and Skills. It formed a partnership with the Hertfordshire Music Service within the Paul Hamlyn Foundation 'Musical Futures' project (www.musicalfutures.org). The teaching-and-learning materials (Green with Walmsley 2006) are downloadable from that site, under 'Personalising Music Learning: Section 2'. The work is indebted to a large number of people, including our Research Officer Abigail D'Amore (née Walmsley) as well as many more in schools and other organisations. All names of teachers, pupils and schools have been made anonymous.

A deeper examination of all the issues discussed in this presentation, and many other issues, is available in Green (2008).

\section{Background and further information}

What makes a group of school pupils cooperate together on a musical task? Certainly motivation is one thing: if they want to do the task, they will cooperate. Is it also the teacher, who supervises them, guides and instructs them? Yes. Is it the task itself, by being broken down into steps at progressive levels of difficulty, or structured into a series of different activities? Again, yes. But what I would like to consider in this presentation, is what makes pupils cooperate when we use alternative strategies in the classroom. I am not saying these strategies involve doing without a teacher altogether, or having no structure at all. But what happens to group cooperation when we deploy 
the teacher and structure the task in a slightly different way to what is normal in most classrooms $?^{1}$

The project which is the topic of this afternoon's talk grew out of my previous book on how popular musicians learn (Green 2002). Amongst other things, that book considered the nature of the musicians' learning practices when they are operating informally, outside educational provision. As a result, I suggested it was helpful to identify five main characteristics of their informal learning practices, which differ quite radically from most formal educational practices. They are:

- that learners always start with music that they know and like;

- that the main learning practice involves copying recordings of real music by ear;

- that learning takes place alone and, crucially, in groups of friends, mostly without adult guidance or supervision;

- that learning is not progressively structured from simple to increasingly complex, but holistic, idiosyncratic and haphazard;

- and that listening, performing, improvising and composing are all integrated throughout the learning process.

The project attempted to adopt and adapt these five characteristics of informal learning, and bring them into the secondary school classroom. Our research took place in altogether 21 schools, although since the research phase to-date, over 2,500 people in schools and other places have downloaded the materials.

The lessons occurred in normal curriculum time, with one lesson of about an hour a week. During the first lesson, each class had a brief discussion of how popular musicians learn informally. The pupils were then told they were going to learn informally, based as far as possible on the five characteristics of informal music learning just identified. So they split into small friendship groups of about 4 or 5 pupils, and went off into separate spaces (practice rooms, corridors, storerooms or 
whatever), taking a CD player (or other recorded-sound player) and a selection of their own choice of music. The task was simply to listen to the music and choose one song or piece. They then had to attempt to play it by ear, using their own choice of instruments as available, and directing their own learning as a group.

This formed the first stage of the project, and went on for about 4 to 6 lessons. After that, we introduced further stages, involving a range of other tasks taking us almost to the end of the academic year. Some of the tasks were more highly structured than the one described here, and some were not. Two of them, tested by a small number of schools, involved an adaptation of informal, aural learning practices in relation to performing classical music. (See Green 2008 for details.) However today, I will focus almost entirely on what happened in relation to group cooperation during the first 4 to 6 lesson stage only.

The role of the teacher was crucial, but all the teachers in the research found their roles quite different from normal. For the first two or three lessons teachers were asked to stand back and observe as much as possible. During that time they tried to understand and empathise with the goals that pupils were setting for themselves. Then they began to act as 'musical models', demonstrating and suggesting how pupils could achieve those goals, rather than correcting or instructing pupils in the normal way.

There were many fascinating findings and outcomes. One main area concerned what pupils learnt as music-makers and music-listeners, as well as the nature of the music-learning processes that many of them seemed to adopt almost naturally. Another concerns what teachers learnt, particularly how their views of their roles developed. However, in this presentation I am going to bypass those areas, which are discussed in Green 2006 and 2008. Instead, I wish to focus on how pupils interacted with each other as group members and as individuals with differing needs and experiences, within this more-than-usually self-directed group ethos. I will attend to three aspects of this. The first concerns group cooperation, particularly in relation to how pupils organised their learning within their groups. The second concerns inclusion with reference to pupils who had different abilities and prior musical experiences. The third again concerns inclusion, but paying attention to pupils who were identified as disaffected, that is, who presented negative attitudes and challenging behaviour, not only in music, but in subjects right across the school. 
What happened in the first few lessons? To being with we seemed to be confronted with chaos, which is exactly what teachers feared. However, on closer examination it became apparent that what appears chaotic can actually contain a kind of order and focus of its own. Here is an example of a group of girls working together at the beginning of the second lesson. They were in a room without a teacher, and were unaware that they were being recorded, although they later gave permission for the recording to be used. You will hear them listening to a couple of different songs, discussing what instruments might be suitable to use, expressing their tastes, discussing which song to choose, thinking about the words, trying out a few beats on the drums, and singing along.

Music is playing then comes to an end. One person claps the beat.

-Hey, can we use the drum thing to make it go along with this?

-Ooh, I like this song.

-I love this song.

-So, just see, is there another one, or are we definitely doing that? Are we definitely doing that?

-I like this song.

Various speech, largely inaudible. Track starts up again.

-Wait, put it back on the other song. Ow!

Largely inaudible talk continues.

-You shouldn't - where's the words?

-It's there.

-Where? Oh right.

12:40 The song starts up again for the second time. There is playing along with the drums, plus talk, going on all the way through.

-No, we could do that thing (crash on cymbal).

-OK, we could do that in the chorus.

-Yeah.

Music plays. Interesting to hear the drummer is playing the vocal rhythms at this very early stage. Up to $14: 00$.

-OK are we going to use the agogo here?

Music plays.

-Shall I count to three? 
Music plays. 14:50

-I've heard you singing before.

-I have.

-You have?

-Yeah, at (inaudible) party on Saturday night.

-Oh God, that was awful.

15:30 Music plays; playing along and talking (about the music) continue.

-Turn it up for a second.

The drumming is getting completely out of time and random.

-Everyone, why don't we all, like sing it?

Track stops.

-Shall we try again, maybe without the drum this time? (Laughter)

-(Drummer says) Sorry!

Here they are in the next lesson, again without a teacher, rehearsing for a performance to the rest of the class. One girl, who says 'Right shall we start then?' seems to be leading the group. At one point there is a disagreement between two girls:

Music plays on the $\mathrm{CD}$; inaudible talk; someone is hitting drum sticks together, then a cymbal.

-Right, right shall we start then?

-I have to go (inaudible), 'cause I have to (inaudible as drum is being played loudly).

Music plays on $\mathrm{CD}$, keyboard and drums.

-It's just you should be doing it by yourself.

-This bit? I haven't worked it out yet.

Music continues, then someone switches the CD off and playing stops. -Sorry, it's just you're doing it by yourself until you hear the drums.

-I have a message from Charlie on my phone.

-Saying what?

Music starts up again, $\mathrm{CD}$ and instruments playing.

-I have to do that bit though, der, der, der, der.

-Right. Wait until it comes though. 
-Is that the start as well?

-No it's not. That bit (inaudible as drums and CD are being played loud) ... at the start, at the very start.

$\mathrm{CD}$ is abruptly turned off.

-You don't have to do all of it. Just-

-Why do you keep stopping it?

-I just - because they wanted to do the other bit, I just (inaudible) do the piano bit by ourselves.

-Why can't everyone just do the beginning bit?

$-\mathrm{Eh}$ ?

-Why can't everyone just do the beginning bit?

-Because you got to have three (inaudible), you need three parts in it.

Track plays with drums.

The performance itself, which took place at the end of the lesson, started off with a keyboard playing along with the $\mathrm{CD}$; then the drums entered forcefully with an upbeat figure ending with a cymbal crash. Three voices entered later, arranged as lead and backing vocals.

As mentioned, in other contexts I have examined how the groups got to such a point in relation to musical skills and knowledge, and the role of the teacher in helping them to do so. But today, the main questions that I wish to focus on concern group cooperation and inclusion. They are: in what ways did pupils, such as these girls and others, cooperate together in their groups; to what extent were pupils with different abilities and experiences able to be included in the activities; and what kinds of responses came from those who were identified as disaffected within the school generally?

\section{Group cooperation in the classroom}

Educational researchers distinguish many different types of classroom groupings. ${ }^{2}$ At one extreme, pupils may be merely sitting together in groups whilst each works on their own individual task. Such a setting is, therefore, not really group learning as such. At the opposite extreme, every member of a group is integrally involved in a 
collective task. Without each person's particular input, the task as a whole would disintegrate. Some theorists refer to this kind of activity as 'cooperative learning', 'collaborative learning', or more extremely, 'co-cooperative learning' within a 'learning community'. It is at this end of the spectrum that the informal music learning project is situated. For whilst there is the possibility that a member of a group may make only a limited input, the role of each individual nonetheless contributes an integral part to the overall musical product.

I can imagine you might be thinking 'But what about the coaster, the freerider, the child who sits and does nothing?' I don't have time to go into this today, but I would ask you to take it on faith that there were actually very few occurrences of this kind of thing. Where they did occur, in nearly every case, the individual concerned was gradually drawn into the activity by others in the group. I would also like to suggest that just because a pupil is sitting apparently doing nothing whilst music plays and others use voices and instruments around them, this does not necessarily mean that they are learning nothing. However, there is no time to go into that argument more deeply today.

The teachers expected group cooperation to be a problem. They anticipated that pupils would waste time, muck around, break equipment, and argue. However, within the first one or two lessons, these opinions changed quite radically. Overall, teachers came to agree that application, responsibility, motivation and cooperation were better than normal; and furthermore, they observed that in general these continued to improve as the year went by. They expressed some considerable surprise about this.

At the end of the first, 4 to 6-week stage of the project, we conducted semistructured interviews with 200 pupils in 40 small groups across 7 schools. We asked only open questions, and did not prompt replies. One question was: 'How well or how badly did your group cooperate during the task?' Only five groups indicated that they had experienced problems, although in most cases this was restricted to the first couple of lessons: 'Some of us didn't cooperated [sic]'; 'We didn't get our work together quickly'; but in the end, 'we knuckled down, and then we done it'. Amongst the remaining 35 groups the response was invariably that cooperation had been 'easy', 'very easy' or 'fine'. Let us consider the types of group cooperation that were involved. 


\section{Group learning}

One aspect involves 'group learning', by which I mean learning that occurs more-orless unconsciously or even accidentally, simply through taking part in the collective actions of the group. This includes learning through watching, listening to and imitating each other during music-making, involving group cooperation in the form of various ensemble skills. As one pupil described it, a girl with learning difficulties and who spoke English as a second language:

-Olivia: We learned how to work in a group and also learn how to, if one person come and another person come, we learnt how to come in and how to come out, and I thought that was great because, it was quite hard, you know when other person playing and another person had to come in after a hard part, but when we get used to it we find it quite easier. I know what to do now.

Pupils also reflected on how they had cooperated, not whilst they were playing or singing, but whilst they were discussing and organising their learning:

-Stacey: In partners, like, I worked with someone on the drums and then they went on the piano, and two people were on the guitars, and that was all sort of like just in partners, so like lots of little groups in one big one...

We asked: 'What, if anything, have you learnt from the project so far?'. Many pupils identified musical skills such as playing instruments, and several reported improvements to their listening abilities (see Green 2008). However, as well as specifically musical outcomes such as those, some pupils also said things like:

-Daniel: I think I've learnt to, like, work more as a team, like listen to each other, whereas before like I used to like, always be speaking over everyone kind of thing, but I've like got used to working as a group now better.

As time went by, a number of pupils became increasingly aware of the makeup of personnel in their group. They were able to reflect on ability differentials, and 
on how to address them through group-organisation. So in most groups, pupils themselves took over the role of encouraging everyone to join in, showing concern about including each other, and discernment about what tasks would be suitable for whom:

-Sophie: Because we got more practice now and we know how to work as a team and we know who's good at what and what who's not good at what and all that.

Not only did pupils say they communicated with each other well, but some said, for example:

-Madeline: [We learnt] how to like communicate with each other a lot more. Because this project, we didn't have teachers to help us, we asked the rest of our group how to do it, so we communicated more.

Many pupils volunteered that the reason why they were able to cooperate and communicate in such ways was because they were allowed to work with friends. Friendship was important, not only for the psychological comfort of group members, but it is also of course crucial to being able to agree upon a choice of music in the first place. For as we know, musical taste is integral to teenagers' identities and social group allegiances.

\section{Peer-directed learning}

The other main aspect of group cooperation that I wish to mention here, is what I refer to as 'peer-directed learning'. This is not a distinctly different aspect from group learning, but is situated further along a continuum, from unconscious, implicit learning via group interaction, towards a more conscious approach, in which knowledge and skills are explicitly and intentionally communicated by one or more group members to one or more others. For example, one group member may explain a technical point, demonstrate how to play a bass line, take charge over how fast the 
group should play, and so on. Peer-directed learning is thus a form of learning through being taught by a peer.

I would like to suggest that a teaching and learning exchange between peers has qualities that are distinct from a teaching and learning exchange between an expert and a novice, or a designated teacher and pupil. Pupils themselves intimated that they had quite a different response to being taught by their peers; and several pupils said they preferred being helped by a peer rather than by a teacher. One reason for this is no doubt the relative absence of power differential existing between peers. For there was a strong feeling that teachers put on pressure:

-Alex: You can do it in your own time, and you're not like being told what to do by the teacher, or, like being fussed around and stuff.

-Daniel: I think [teaching yourself] is like, a bit better 'cause like the teacher is always behind you kind of thing, and you're like a bit under pressure...

Another reason may be that many pupils are less intimidated by and alienated from each others' knowledge and expertise. In particular, many pupils said they felt that teachers use too much technical vocabulary and theory. By contrast, peers often used non-verbal ways to help each other, based around listening, watching and imitating. They avoided technical vocabulary - mainly because they didn't know any themselves - in favour of gestures and the use of sonic materials and phrases to indicate meanings, as in the quote below:

-Michael: Just play it once, just play it once.

-Ross: I'll go (plays guitar riff).

-Michael: You don't need to play that, so when I go (starts to play) if you be silent (guitar plays) and then you go silent for (bass plays).

-Ross: I know! So I'll just go (guitar plays).

As the educationalist R. E. Slavin (1995, p. 4) puts it: 'students can do an outstanding job of explaining difficult ideas to one another by translating the teacher's language into kid language'. Another way to put this might be that pupils are 
sometimes better at getting inside each others' 'zones of proximal development', to use Vygotskian terminology, than teachers are.

Very importantly, not only those being taught, but those doing the teaching benefited. There is evidence from a range of research that the act of teaching can enhance learning for the peer teacher him or herself (see e.g. Slavin 1995).

\section{Leadership}

Both group learning and peer-directed learning involved, in most groups, an amount of leadership by one or more members of the group. One interesting issue was that teachers expressed surprise about the extent to which leaders emerged in many groups. Furthermore, teachers were often surprised that the particular individuals who emerged as leaders were, in many cases, ones who had not previously shown themselves to be either able or willing to participate successfully or enthusiastically in music lessons, and who were not expected to help each other.

I will now illustrate this through a little story relating to one pupil. Immediately before the project started, Hana was described by her Head of Music as a 'madam', with 'an attitude' and someone who would be likely to cause trouble. In the previous two years at the school she had achieved little or nothing in music lessons, and had shown no signs of ability or interest. Hana described herself as having been a troublemaker. She referred to music as 'a load of rubbish'. All she could remember about previous lessons was worksheets.

-Hana: The reason I remember about worksheets is because I was always in isolation in music because I hated it that bad, I always got kicked out of it [laughter]. Until this year...

Now here she is participating in group work, in a field-recording from the fourth lesson of the project. Note how her leadership is not disputed by others in the group; and how she and another girl, Kimberley, who also displays leadership, work constructively alongside each other rather than battling against each other.

(General noise is going on. Hana tries to quieten everybody down:) 
-Hana: One, two, three, BEEEEEP!

General noise from talk, CD recording and instruments.

-Hana: Everyone! Ssshhh! Ssshhh! Ssshhh, ssshhh, ssshhh, ssshhh, ssshhh! (Noise quietens.) Right Jenny, Jenny, to start opening, to start the music once, Jade, what I think you should do, is go 'one, two, three, four', and then start, and then it goes, two counts in, and then-

-Jenny: Yeah, but we need somebody to come in at the beginning.

-Liz: Have you got a battery in your bag?

-Hana: all you lot just be quiet, until it gets to look (inaudible). I'll count, I'll count (inaudible, various voices and music.)

-Kimberley: (Into the microphone) I'll just go, (Hana is still giving instructions in background.) 'one, two, three, four, five, six, seven, eight' everyone. Yeah? So you do (inaudible) at the beginning, and then it can go, it can go, yeah, with the help of (inaudible). And then I'll go 'one, two, three, four, five, six, seven, eight' and everyone comes in.

Music begins then stops.

-Hana: Right, everyone ready? So you lot sshh, just be quiet for this first bit and then I'll count you in, yeah? Yeah, is everyone ready?

-Jenny: Shall I go?

-Hana: OK, sshh.

-Jade: Are we gonna need this?

-Hana: No, no, that's fine. Right, one, two, three, go.

CD starts and Kimberley sings.

\section{Teachers' views of group cooperation}

As I mentioned earlier, in interviews the teachers strongly agreed that group cooperation had been high. They also said that group learning, peer-directed learning and leadership had been more evident and more effective than they had seen before, or had anticipated. As just one, out of many possible examples: 
-Sandra: ... I think their group work, and working as a team in a positive way has improved a lot. I haven't seen anybody arguing in the same way that you quite often get with kids, 'Oh, that instrument, Oh I don't want to do that'. They seem to have chosen an instrument and stuck to it and it's been accepted that that's what they're doing. And there has been a huge amount of positive encouragement between the students, so students who are naturally good at this are jumping in to help others, and they're helping others with their own parts, and they're helping others by playing to them and demonstrating what to do, and it's been, it's been really interesting to watch that come out. Whereas ordinarily I think people tend to just play their bit and then go off task and have a big fight over who's doing what, and not always work as positively in a group as they have done with this.

\section{The cooperative learning group as an organic system}

What are the reasons why the groups cooperated and organised themselves in ways that helped their learning? One reason concerns motivation. I do not have time to go into this today, but I hope it will suffice to say that most pupils found the task highly motivating. However much they were or were not enjoying their music lessons before the project started, they also found the project quite different and unexpected. 'We've never done anything like this before'. Over two years, across 17 of the schools, 95 per cent of pupils reported they preferred the project's approach to the 'normal' curriculum. In addition, we and the teachers observed many signs which suggested that enjoyment was high. For example, one was that pupils played together without stopping for lengthy periods of up to 6 or 7 minutes, during which they often appeared to be experiencing a state of 'flow', as identified by the psychologist Csikszentmihalyi (1990, 1996). They also appeared to be involved in 'play' rather than 'work', as identified by J. S. Bruner (1979).

Pupils themselves affirmed these claims in their interviews, again without being prompted. They frequently and spontaneously described the project as 'fun'. They told us that they very much liked having choice. This included not only choice over music and instruments, but moreover, choice over the learning strategies. Overall, the majority preferred directing their own learning - with help from teachers 
only or mainly when it was asked for - rather than being taught in a more instructional, more normal way.

All these issues warrant closer inspection (see Green 2008 for more details). But to pick out what is most relevant for today's presentation, many pupils suggested that the relative absence of instruction from teachers actually had a beneficial effect, not only on their enjoyment and their ability to learn, but also on their ability to work together cooperatively as a group. We can surmise that, as well as having fun, choice and so on, there was another, overarching reason for this: that the collective nature of the learning task, and the fact that all group members had to make an input into the final outcome, resulted in an organic type of group cohesion, in which negotiation and success were in the interests of the members.

Contrast that to the hierarchical relationship which normally exists in teacherlead activities. For example, let's say a teacher asks a class for an answer to a question; several pupils put up their hands; one girl is selected to give the answer; she gets it wrong; another girl is selected; she gets it right. As Slavin puts it (1995, p. 4), interchanges such as that are likely to make pupils compete and want each other to fail. But in cooperative learning, success depends upon every member of the group getting it right. Therefore students want each other to succeed, and will help each other to do so.

\section{Inclusion: ability, achievement and differentiation}

Some teachers were initially concerned that the project would not be accessible to pupils with low ability. However, as time went by many teachers expressed surprise that such pupils were taking part and achieving in ways they had not witnessed before. For example:

-Debbie (Head of Music): Well it's really weird, because one of the boys I was thinking of who was singing, he gave up on guitar because he thought 'Oh I'm not going to do it' ... And actually today ... he was one of the best guitarists there; and he's really low ability, he's statemented [given additional support and on the Special Needs register], he can hardly write his name. And this is 
what's really opened my eyes to this project. ... Kids who I wouldn't have expected have come out with things...

There was also general agreement that the project was able to stretch pupils at the opposite end of the spectrum, including those who were most able and those who took additional instrumental lessons:

-Yasmin (Head of Music): And the stronger, more musically able children, I've noticed a huge improvement just in their manner and attitude towards the subject, that they just want to get on with it, they just want to be able to produce more and more music. ... No, I don't think I've noticed any deterioration, absolutely none.

Teachers noticed that pupils with a range of ability displayed their musicality in new ways, or as one teacher put it, they 'revealed some hidden musicality':

-Hugh (Assistant Music Teacher): I think I've seen and heard that kids can produce slightly different outcomes, because, you know, what we plan to do, we also kind of plan an expected outcome from what they're going to achieve. Whereas because the project was a bit more open and you know it's, the kids achieved different things on different instruments that we might, you know because they chose their own, suddenly I'm, I'm slightly more aware of who can play what and what they can do on different instruments. Rather than saying 'Today we're doing this on these particular instruments'... Yeah, it did reveal it, definitely revealed some hidden musicality. Mantsebo, for instance, I didn't know he was quite so good on the drum kit. ... Now I know he can play that well.

Overall, there was agreement that the task involved what is known as 'differentiation by outcome'. In other words, all pupils were set the same task, but it was adaptable to the differing abilities of individuals, not by virtue of being divided up into separate, progressive levels of difficulty, but according to what each individual produced as the outcome: 
-Richard (Head of Music): And also because they're different skills like, you know, it's totally differentiated. But, it is differentiated by outcome rather than task, which is another sort of thing I've had to struggle with. But at the end of the day, each pupil has actually made significant progress. And I have been convinced, you know, even when the groups performed. There are one or two individuals, well several individuals, who I thought 'No I don't, I would never give them the credit to be able to do that' you know, sort of bass lines on bass guitars you know, there's a girl in one of the extracts, and I just thought there's no way she would ever have been able to do, have the option to do that, in my standard music curriculum. And so that's been really good as well...

As the project went on, teachers came to question how they had previously judged low and high musical ability.

\section{Inclusion: disaffected pupils}

I have already mentioned that several individuals who took up leadership roles and who showed ability, were pupils who had not been expected to do so by their teachers. Now I would like to consider some further issues, particularly in relation to pupils who were identified as disaffected, not only in music but other subjects too. I will do this through two short stories.

\section{Tyler: Imaginative play and the importance of musical delineation}

Tyler was on a school initiative to focus on underachieving boys. Sandra, his Head of Music, put a report into my hands one day, which she had dug out from the records during the previous year. It read:

Tyler has failed to do any work in music for the past two weeks. In today's lesson, he did not have any equipment and was constantly out of his seat. There were a number of silly instances including hiding behind the door, playing with the projector screen, etc. He was frequently talking, calling out 
and interrupting, despite warnings, and at the end he was asked to stay behind so that I could enter a detention in his diary. He did not have his diary and continued arguing about the punishment. He claimed that it was not his fault $\ldots$ and that it was my problem. He finally walked off saying that he was not coming to the detention, that he hated me and that I was ugly!

Unsurprisingly, Tyler gained nothing but D and E grades - that is, the lowest - for both effort and achievement, throughout that year.

This is how Sandra described Tyler, and others in his group who had also been identified as underachieving, during the year of the project:

-Sandra: Well there's one group in particular that were causing me concern because they'd grouped themselves together. And they were three boys (Tyler, Bob and Chris) who had had quite serious behavioural problems in music last year and were on the verge of being removed from the class and not able to take part anymore. And within that group they've actually been almost the most positive group that there is. One student (Tyler) comes early to every lesson to set up the equipment. They just work together so positively. There's been no problems with any of the behaviour we saw last year...

During the project, Tyler and his peers gained mainly A grades for effort and achievement. Furthermore, and more importantly for today's paper, they negotiated constructively and enthusiastically with each other.

Here is an extract from a recording of the group working together, again without a teacher in the room. This is actually during the second stage of the project, but they were engaged on a similar task. What I would particularly invite you to focus on, is the way Tyler is talking about how he thinks the group should stage their final performance for the rest of the class.

-Tyler: I should come in first, yeah, I'll be on the drums, and I should go (plays a rhythm with a cymbal).

-Ian: Yeah and you could have a steady beat. (Tyler plays the Dizzee Rascal drum rhythm.)

-Chris: Oh, I wonder where you got that from! 
-Ian: Yeah, but you could have Bob come in, and then we could come in on the guitars.

-Tyler: What do you mean, like walking in on the guitar?

-Ian: Yeah.

-Tyler: I could just be going (plays a rhythm).

-Ian: Yeah, Tyler will start doing that and then Bob can-

-Bob: No!

-Tyler: No, I'm not on about that. When we start the performance-

-Ian: Yeah, that's what I mean. You can start, and then Bob can come in and then I'll walk in.

-Tyler: I could go (starts playing drum rhythm, Bob starts playing piano part). And then I'll press play, and we can all go (plays drums).

A keyboard and guitar are also being played. All come to a stop.

-Tyler: Did you hear that? No, shush, listen.

He plays loud and fast on the drums. Inaudible comments from others.

Tyler finishes with a cymbal crash.

-Chris: That's wicked!

-Tyler: Bloody 'ell that kills your arms, like (plays loud again).

Instruments being played; some vocalisations.

-Tyler: Stop a minute. I've had a phat idea, yeah. I could be going like that, (plays again) and then Jack just walks in, sits down onto his piano or whatever he's playing, and I could go, and when Jack sits down I could go, I could go (plays again at some length), and then you come in, skid on your knees and go BOOOOWWWE!

Notice the role of imaginative play here concerning the music's extra-musical, cultural connotations, or what I elsewhere call delineations: the planned dramatic entry into the room; the skidding on the knees, and so on. A similar attention to delineations as part of stage presentation occurred in a group of girls, who were incidentally designated as the 'lowest ability in the class'. They were doing the song 'It's Raining Men', and spent time cutting out little paper men and searching for some umbrellas to use in the performance. Pupils in some other groups were keen to dance as a part of their music-making. All these approaches invoke cultural practices, meanings and values which lie beyond the music's sonic properties and their 
interrelationships, or what $\mathrm{I}$ have in the past referred to as 'inherent musical meanings' (e.g. Green 1997, 2005 or 2006).

So often in music education we shut out cultural connotations or delineations concerning music's wider contexts and uses, as not being a part of the 'proper' lesson and not involving a direct engagement with the sonic properties of music: 'No you can't skid on your knees - you need to hold the guitar properly; no you can't cut out paper men - you're supposed to be playing your instruments; no you can't dance you need to learn musical skills'. But by encouraging free play of the imagination for pupils to express themselves in relation to the music's delineations, I would suggest, we are also opening the door into the music's sonic properties and their relationships as well. This may be particularly the case for pupils who have difficulty with academic work, or who come across as disaffected in school.

Connor: 'You're becoming a musician I suppose': getting to grips with music's sonic properties

Now I want to consider the issue from the opposite angle - that is, the sonic properties of music and their interrelationships. In a different school, Connor was vocal on how meaningless and generally unpleasant he had found the curriculum in the year before the project: 'I used to hate, dreading coming to music...'. He was described by his Head of Music as 'really tough' and an example of a 'problem kid' from a 'nightmare class'. Her view of his whole group's work was negative. She described them as the 'strong personality group' and the 'cool' group, who 'got the least amount done' and had 'nothing to show at the end' of the lesson. She believed that Connor was largely responsible for this, and after the second lesson he was excluded from class. But his group-members said they couldn't work properly without his leadership, and begged for him to be allowed back in. This wish was granted on condition of good behaviour. Here is a field note taken by Abigail, the project's Research Officer in the lesson following that:

Spent about 15 minutes with Connor's group. They were on task the whole time. Connor is very much leading this group. Initially they were all practicing their riffs separately (but along to the CD so sort-of together), and there was a 
slightly chaotic feel... After about eight minutes Connor stopped them all and said they needed to work out how to fit it all together. They switched off the $\mathrm{CD}$ and Connor got them to each play their parts in turn. I suggested to them that they should think about how to start and end their performance, but gave them no other help, and Connor immediately grasped onto this idea and worked out a sequence for how they should all come in and how they should fade out at the end.

At the end of the lesson, the class teacher, Debbie, asked Connor how well his group had been getting along:

-Connor: Well, we didn't have nothing last week, so to have that was really good, the tune was quite good.

-Debbie: I have to say Connor, that I totally agree with you. Last week I didn't think you were going to produce anything, but today all three of you really pulled yourself together and sorted it out. Well done.

She also asked how he got on with the drum beat:

-Connor: Well I asked Mr X [the assistant teacher] to do it, and he showed me. He just went (plays basic rock beat), but I thought, 'Nah that don't sound like the beat', so I thought (plays beat, actually more accurate than the one Mr. X had shown him).

Connor was deeply encultured in the music he was attempting to play, more so than the teacher who showed him the drum rhythm. He knew what an appropriate drum beat should sound like. This affirmed his cultural identity in ways that he felt had been denied in previous lessons. But not only that, for it also put him, rather than the teacher, in the role of the 'knower' and the 'expert' with regard to, not just the cultural connotations or delineations of the music, but also its inter-sonic relationships.

At one point during the fifth lesson of the project, the teacher said to the group: 
-Debbie: Superb, and it really works doesn't it? Absolutely brilliant. Did you all listen to the keyboard as well?'

-Connor: It sounds like 'Postman Pat' a bit (plays keyboard notes).

'Postman Pat' is a theme tune for a TV programme, aimed at very young children, whose main character is an endearing cartoon postman. It is fair to suggest - based not only on speculation but on what many pupils told us - that if the teacher had instructed Connor to play a tune with such childish delineations, his reactions would have been in no uncertain terms, negative. But he was happy to mention the tune himself, I would suggest, not only because the idea came from him rather than from a teacher, but moreover, because his direct engagement with the inter-sonic properties and relationships of the music had overridden what he would otherwise have considered to be beneath him in the realm of delineation. Connor indicated that he much preferred project lessons to 'normal lessons'. This was not only because they were more fun, nor just that in his view, they were more realistically related to the world outside the school; but also because of his close relationship with the sonic materials and interrelationships of the music. As he put it: 'You're becoming a musician, I suppose'.

This overriding of negative delineations through concentration on inter-sonic meanings via self-directed learning and peer-group cooperation, is one of the factors that, I would suggest, allowed many other pupils, including those with 'hidden musicality' like Hana, and those who were disaffected like Tyler or Connor, to respond positively to the project. The project strategies came from a study of how popular musicians learn informally. Although their learning practices were adapted for the classroom, fundamentally they had been developed by learners for themselves and each other, rather than being developed by teachers. If there is any strength in the strategies, I think that is where it must lie.

\section{Bibliography}

Bennett, N. and Dunne, E. (1992) Managing Classroom Groups, Hemel Hempstead, Simon and Schuster. 
Bielaczyc, K. and Collins, A. (2000) 'Learning communities in classrooms: a reconceptualisation of educational practice'. In Reigeluth, M. (Ed), Instructional-Design Theories and Models, Vol. 2, Mahway, New Jersey, Lawrence Erlbaum.

Bruner, J. S. (1979) 'Play as a mode of construing the real'. In Katz, S. L. (Ed), Proceedings of the Yale Conference on the International Year of the Child, New Haven, CT, Yale University Press; reproduced in J. S. Bruner (2006), In Search of Pedagogy, Vol. II: The Selected Works of Jerome S. Bruner, Abingdon, New York: Routledge, pp. 57-64.

Csikszentmihalyi, M. (1990) Flow: The Psychology of Optimal Experience, New York, Harper and Row.

Csikszentmihalyi, M. (1996) Creativity: Flow and the Psychology of Discovery and Invention, New York, Harper Perennial.

Faulkner, R. (2003) 'Group composing: pupil perceptions from a social psychological study'. Music Education Research, 5, 2.

Green, L. (1997) Music, Gender, Education, Cambridge, Cambridge University Press.

Green, L. (2002) How Popular Musicians Learn: A Way Ahead For Music Education Aldershot, Ashgate Publishers.

Green, L. (2005) Musical meaning and social reproduction: a case for retrieving autonomy. Educational Philosophy and Theory, 37, 1, 77-92.

Green, L. (2006) Popular music education in and for itself, and for 'other' music: current research in the classroom. International Journal of Music Education.

Green, L. (2008) Music, Informal Learning and the School: A New Classroom Pedagogy Aldershot, Ashgate Publishers.

Green, L., with Walmsley, A. (2006) Classroom Resources for Informal Music Learning, downloadable from www.musicalfutures.org, Personalising Music Learning Teachers' Resource Pack, Section 2; or www.dfes.gov.uk; available in hard copy from the Paul Hamlyn Foundation, 18 Queen Anne's Gate, London SW1H 9AA.

Jeffrey, B. and Craft, A. (2001) 'Introduction: the universalization of creativity'. In Craft, A. J., B. and Leibling, M. (Ed), Creativity in Education, pp. 1-13. London, Continuum.

Kincheloe, J. L. and Steinberg, S. R. (Eds) (1998) Unauthorised methods: strategies for critical teaching, London, Routledge. 
Lines, D. (2005b) 'Improvisation and cultural work in music and music education'. Educational Philosophy and Theory, 37, 1.

Morgan, L., Hargreaves, D. \& Joiner, R. (1997) 'How do children make music? Composition in small groups'. Early Childhood Connections, Winter 1997/8, $15-21$.

Rodriguez, C. (Ed) (2004) Bridging the Gap: Popular Music and Education, USA Music Educators' National Conference: The National Association for Music Education.

Stålhammer, B. (2006a) Musical Identities and Music Education, Orebro, Universitetsbiblioteket.

Slavin, R. E. (1995) Cooperative Learning: Theory, Research and Practice (2nd edition), Allyn and Bacon.

Tagg, P. (1998) 'The Göteborg connection: lessons in the history and politics of popular music education and research'. Popular Music, 17, 2.

Vakeva, L. (2006) 'Teaching popular music in Finland: what's up, what's ahead?'. International Journal of Music Education, 24, 2.

Watkins, C. (2005) Classrooms as Learning Communities: What's in it for Schools, London, Routledge.

Wiggins, J. (2006) 'Compositional process in music'. In Bresler, L. (Ed), International Handbook of Research in Arts Education, pp. 451-67. New York, Springer Press.

${ }^{11}$ Scandinavian countries are probably the closest to employing similar approaches, although of course within Scandinavia this differs from country to country and school to school. See for example Vareka (2006), Faulkner (2003), Stalhammar (2006), Tagg (1998) for discussions and information. There is a growing literature on popular music and informal learning practices in relation to music education. For general discussions see e.g. Rodriguez (2004), Lines (2005), or the special issues of the journals, Research Studies in Music Education 13 (1999), or International Journal of Music Education no. 36 (2000).

${ }^{2}$ For discussions see e.g. Bennett and Dunne (1992), Slavin (1995), Bielaczyc and Collins (2000), Kincheloe and Steinberg (1998), Watkins (2005); with relation to 
creativity, e.g. Jeffrey and Craft (2001); and with relation to music education, e.g. Faulkner (2003), Morgan et al (1997), Wiggins (2006). 